\title{
Isolation of polysaccharides
} \section{and anti-inflammatory activity in LPS-stimulated THP-1 cells}

\author{
Min Zhang ${ }^{1}$, Junwen Wu' ${ }^{1}$, Juanjuan Han ${ }^{1}$, Hongmei Shu and Kehai Liu ${ }^{1,2^{*}}$
}

\begin{abstract}
Dendrobium officinale stem is rich in polysaccharides, which play a great role in the medicinal effects of this plant. However, little was known about the polysaccharides from Dendrobium officinale leaves. Two kinds of polysaccharides in the leaves, DLP-1 and DLP-2, were obtained by hot water extraction, alcohol sedimentation and chromatographic separation (DEAE-52 cellulose column and Sephadex G-100 column). The average molecular weights were determined as 28,342 Da and 41,143 Da, respectively. Monosaccharide compositions were analyzed using gas chromatography-mass spectrometer. DLP-1 was composed of D-(+)-galactose, DL-arabinose, and L-(+)-rhamnose with a molar ratio of 3.21:1.11:0.23, and traces of D-xylose, D-glucose, and D-(+)-mannose. DLP-2 was consisted of D-glucose and D-(+)-galactose with a molar ratio of 3.23:1.02, and traces of D-xylose, DL-arabinose. Then, we established inflammatory cell model by LPS acting THP-1 cells to investigate the anti-inflammatory effects of DLP-1 and DLP-2. The results indicated that DLP-1 $(5 \mu \mathrm{g} / \mathrm{mL})$ and DLP-2 $(50 \mu \mathrm{g} / \mathrm{mL})$ were effective in protecting THP-1 cells from LPS-stimulated cytotoxicity, as well as inhibiting reactive oxygen species formation. In addition, both DLP-1 ( $5 \mu \mathrm{g} / \mathrm{mL})$ and DLP-2 $(50 \mathrm{\mu g} / \mathrm{mL})$ significantly suppressed toll-like receptor-4 (TLR-4), myeloid differentiation factor (MyD88) and tumour necrosis factor receptor-associated factor-6 (TRAF-6) mRNA and protein expression in LPS-stimulated THP-1 cells.
\end{abstract}

Keywords: Dendrobium officinale, Polysaccharides, THP-1 cells, Anti-inflammatory properties, LPS/TLR-4 signal pathways

\section{Introduction}

Dendrobium officinale Kimura et Migo belongs to Dendrobium Sw., Orchidaceae and widely distributes in the tropical and subtropical areas [1]. The stem is medical part of Dendrobium officinale in China and included in Chinese Pharmacopoeia [2]. Its stem is usually processed into one of the traditional Chinese medicine named "Tiepishihu" after twisted into a spiral while baking and used as a tonic for more than 2000 years due to its exceptional effect [3-6]. Also, it could be either chewed directly or

\footnotetext{
*Correspondence: khliu@shou.edu.cn

${ }^{1}$ Department of Biopharmaceutics, College of Food Science and Technology, Shanghai Ocean University, 999 Hucheng Ring Road, Lingang New City, Shanghai 201306, China

Full list of author information is available at the end of the article
}

stewed in porridge, soup, and dishes as a high-quality food in diets [7]. However, Dendrobium officinale leaves have been used as neither medicine nor food and often discarded as waste, which not only causes environmental pollution, but also wastes this valuable resource.

The current research on Dendrobium officinale also focuses on stems, and surprisingly little was known about leaves until now. In fact, the stems and leaves originate from the same plant, so Dendrobium officinale leaves should have a great range of potential utilities and a prospect of development in food, medical and health care. For example, Dendrobium officinale leaves exhibited good auxiliary therapeutic effect on hypertension, hyperglycemia, hyperlipidemia and other similar symptoms as well as promoting health when serving as tea $[8,9]$, and there was also a research indicated that Dendrobium officinale 
leaves could enhance the $\mathrm{T}$ lymphocyte proliferation, the delayed type hypersensitivity and NK cell function of female rats after two generation reproduction [10]. Therefore, Dendrobium officinale leaves are also worth researching.

Dendrobium officinale stems contain bioactive phytochemicals, such as polysaccharide, dendrobine, sesquiterpenoids and volatile components, but the predominant one is polysaccharide [11]. Polysaccharides, along with proteins, nucleic acids and lipids, are primary class of biological macromolecules [12], and are very crucial since they have tremendous medicinal values [13]. Tons of studies on polysaccharides from Dendrobium officinale stems have achieved great progress. The polysaccharides from Dendrobium officinale stems could exert immunoregulatory activity in vitro by means of promoting splenocyte proliferation, enhancing natural killer cell-mediated cytotoxicity and stimulating of cytokine secretion of both splenocytes and macrophages [14]. In consideration of homology relationship between the stems and leaves, polysaccharides should be main active component in Dendrobium officinale leaves and rich in content. So the polysaccharides from Dendrobium officinale leaves (DLP) were chose to be the resear ch object of this study. On basis of preliminary studies of polysaccharides in stems, the anti-inflammatory activity of polysaccharides in leaves was investigated in this study. To the best of our knowledge, there is no report on the isolation and anti-inflammatory activity of the polysaccharides from Dendrobium officinale leaves in the literature.

THP-1, a human leukemia monocytic cell line, has been extensively modeled and used for investigating antiinflammatory effects of compounds due to its unique characteristics [15]. The cells were usually stimulated with LPS, being in an activation state. Furthermore, LPS and food compounds were often simultaneously applied to THP-1 cells to investigate food compounds for inflammation modulating effects by gene expression response analysis [16]. In this contribution, we established inflammatory cell model using LPS acting THP-1 cells, by means of which to investigate the effects of DLP-1 and DLP-2 on the cell viability, ROS generation, and the TLR4, MyD88 and TRAF-6 expression in LPS/TLR-4 signal pathways, including mRNA and protein expression, to explore these two polysaccharides' anti-inflammatory activity and mechanism.

\section{Results}

Isolation of polysaccharides DLP-1 and DLP-2

Two completely separated fractions, $a$ and $b$, were obtained after DLP was eluted through a DEAE-52 anion-exchange column (Fig. 1A) and further purified by Sephadex G-100 gel filtration column. Their elution curves in Fig. 1B, C were displayed as two single narrow symmetrical peaks, explaining for homogeneous components polysaccharides denominated as DLP-1, and DLP-2.

\section{Molecular weight and monosaccharide composition of DLP-1 and DLP-2}

The average molecular weight and monosaccharide composition were determined by GPC and GC-MS. The standard sample of PEG was used for calibration curve establishment. The results showed that the average molecular weight of DLP-1 and DLP-2 were 28,342 Da and 41,143 Da, respectively (Table 1). DLP-1 was consisted of $\mathrm{D}-(+)$-galactose, DL-arabinose, and $\mathrm{L}-(+)-$ rhamnose in a mole ratio of 3.21:1.11:0.23, and traces of D-xylose, D-glucose and D-(+)-mannose. DLP-2 was consisted of $\mathrm{D}$-glucose and $\mathrm{D}-(+)$-galactose in a mole ratio of 3.23:1.02, and traces of D-xylose and DL-arabinose (Table 2).

\section{Effects of DLP-1 and DLP-2 on cell viability and ROS generation in LPS-stimulated THP-1 cells}

As shown in Fig. 2, LPS-stimulated cytotoxicity could be suppressed by DLP-1 and DLP-2 and this effect appeared to be dose-related. When the concentrations reached $5 \mu \mathrm{g} / \mathrm{mL}$ and $50 \mu \mathrm{g} / \mathrm{mL}$, DLP- 1 and DLP-2 were able to completely protect the THP-1 cells against LPS-stimulated cytotoxicity, respectively. Thus, the concentrations of DLP-1 and DLP-2 were chosen for further research of anti-inflammatory activity.

Compared with untreated THP-1 cells, ROS generation in LPS-stimulated cells increased significantly and the mean fluorescence intensity was enhanced remarkably from $56.98 \pm 1.63$ (a.u) to $91.59 \pm 1.81$ (a.u) (Fig. 3). However, the addition of DLP-1 and DLP-2 resulted in a significant reduction of ROS formation in LPS-treated cells $(P<0.01)$. These results indicated that $5 \mu \mathrm{g} / \mathrm{mL}$ DLP-1 and $50 \mu \mathrm{g} / \mathrm{mL}$ DLP-2 could inhibit ROS generation effectively. ROS are known to play an important role in the activation of several pro-inflammatory genes. DLP-1 and DLP-2 exhibited anti-inflammation activity through suppressing LPS-induced ROS generation in this study.

\section{DLP-1 and DLP-2 influenced the TLR-4, MyD88 and TRAF-6 signal transduction pathways}

From Fig. 4, LPS treatment led to a significant up-regulation of TLR-4, MyD88 and TRAF-6 mRNA expression. When DLP-1 or DLP-2 was added to the LPS-stimulated THP-1 cells, their mRNA expression declined observably, even lower than the original level (the cells treated with nothing). 

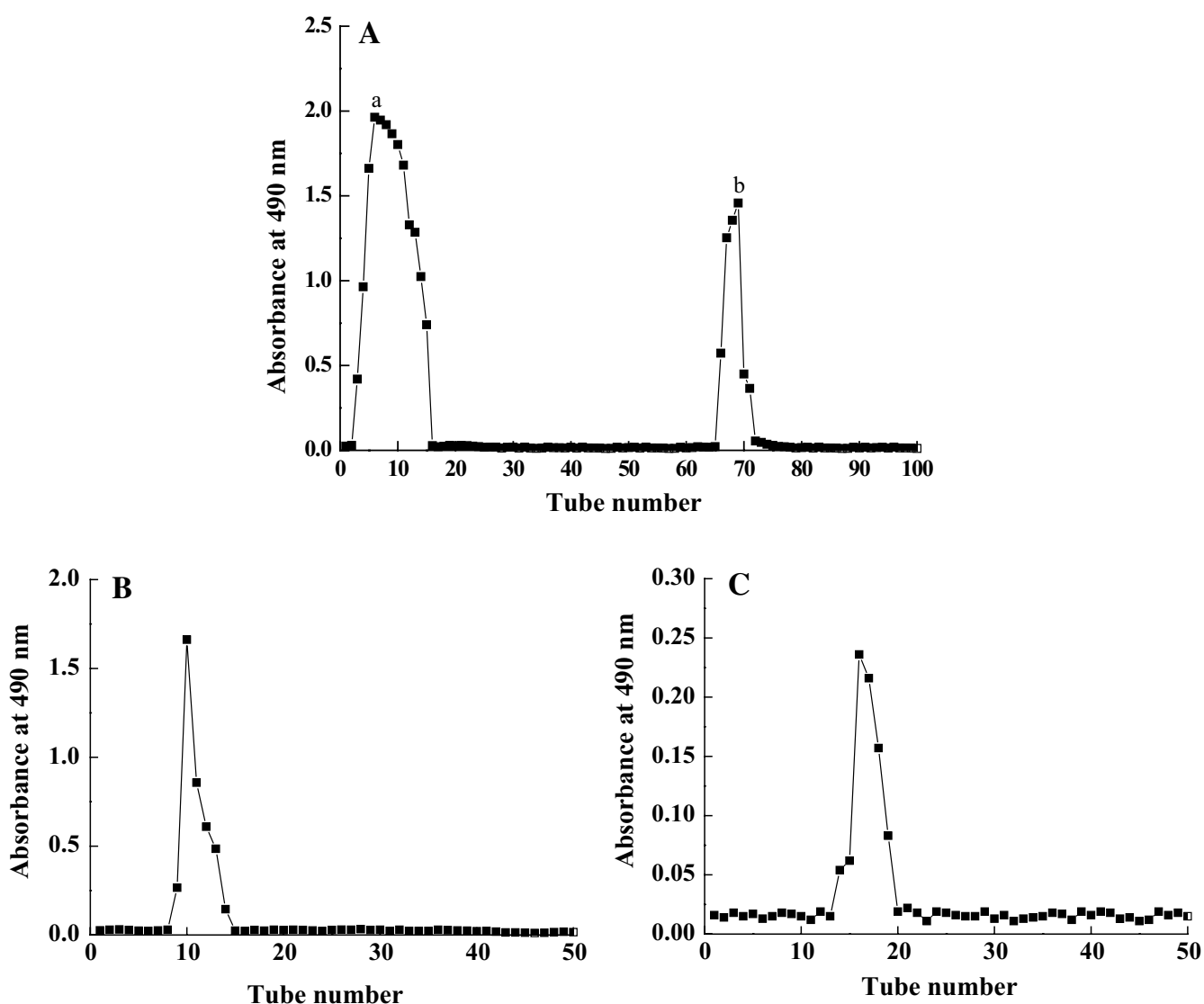

Fig. 1 Purification of polysaccharides. A DEAE-52 anion-exchange column chromatography elution curve of crude polysaccharide extracted from Dendrobium officinale leaves. B, C Sephadex G-100 column chromatography elution curves of fraction a and b

Table 1 GPC analysis of DLP-1 and DLP-2

\begin{tabular}{lllrrr}
\hline Dist name & Mn & MW & MP & MZ & MZ+1 \\
\hline DLP-1 & 17,382 & 28,342 & 8294 & 44,869 & 60,951 \\
DLP-2 & 24,328 & 41,143 & 12,613 & 81,563 & 134,773 \\
\hline
\end{tabular}

Table 2 GC-MS analysis of DLP-1 and DLP-2

\begin{tabular}{llllll}
\hline Monosaccharide & \multicolumn{3}{l}{$\begin{array}{l}\text { Fragment area percent } \\
(\%)\end{array}$} & & Mole ratio \\
\cline { 2 - 3 } & DLP-1 & DLP-2 & & DLP-1 & DLP-2 \\
\hline L-(+)-Rhamnose & 0.75 & - & & 0.23 & - \\
DL-Arabinose & 22.37 & 1.10 & & 1.11 & - \\
D-Xylose & - & 0.90 & & - & - \\
D-Glucose & - & 76.10 & & - & 3.23 \\
D-(+)-Galactose & 77.60 & 28.00 & & 3.21 & 1.02 \\
\hline
\end{tabular}

Consistent with the mRNA expression, marked increase of the TLR-4, MyD88 and TRAF- 6 protein expression levels could be observed in the THP-1 cells after treated with LPS alone. After co-treatment with DLP-1 or DLP-2, their protein expression was more or less reduced. These results clearly evidenced that DLP-1 and DLP-2 could inhibit the TLR-4, MyD88 and TRAF- 6 at the mRNA and protein levels in LPS-induced THP-1 cells.

\section{Discussion}

It has been known that the polysaccharides from Dendrobium officinale stems have good medicinal value [17-19]. Given the homology of the stems and leaves, we initially thought their polysaccharides would have structural similarities, but this was not the case. The preliminary research showed that mannose and glucose were the main monosaccharide components of the 

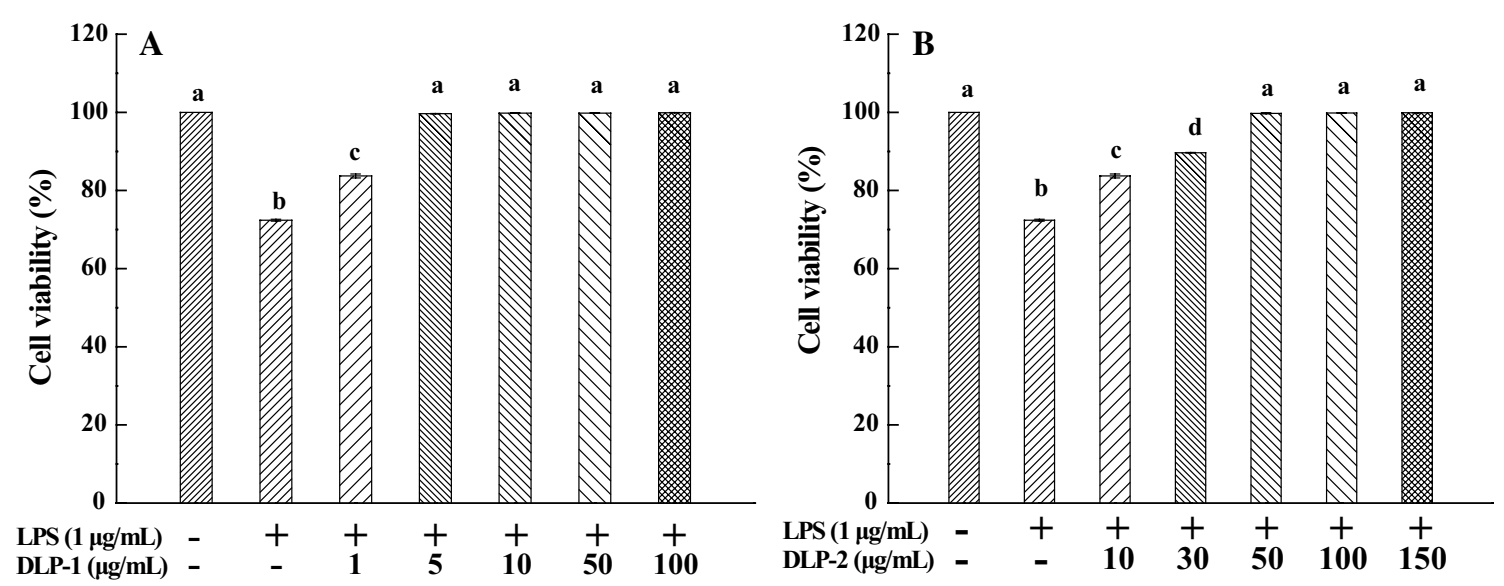

Fig. 2 Effects of DLP-1 and DLP-2 on cell viability. A Cells were treated with LPS $(1 \mu \mathrm{g} / \mathrm{mL})$ for $24 \mathrm{~h}$ in the absence or presence of DLP-1 at different concentrations $(1,5,10,50$ and $100 \mu \mathrm{g} / \mathrm{mL})$. B Cells were treated with LPS $(1 \mu \mathrm{g} / \mathrm{mL})$ for $24 \mathrm{~h}$ in the absence or presence of DLP-2 at different concentrations $(10,30,50,100$ and $150 \mu \mathrm{g} / \mathrm{mL})$. Cell viability was measured using MTT assay. Values were mean $\pm S D(n=6)$; bars with the same letter were not significantly different between groups at $P<0.05$, in accordance with Duncan's multiple range test
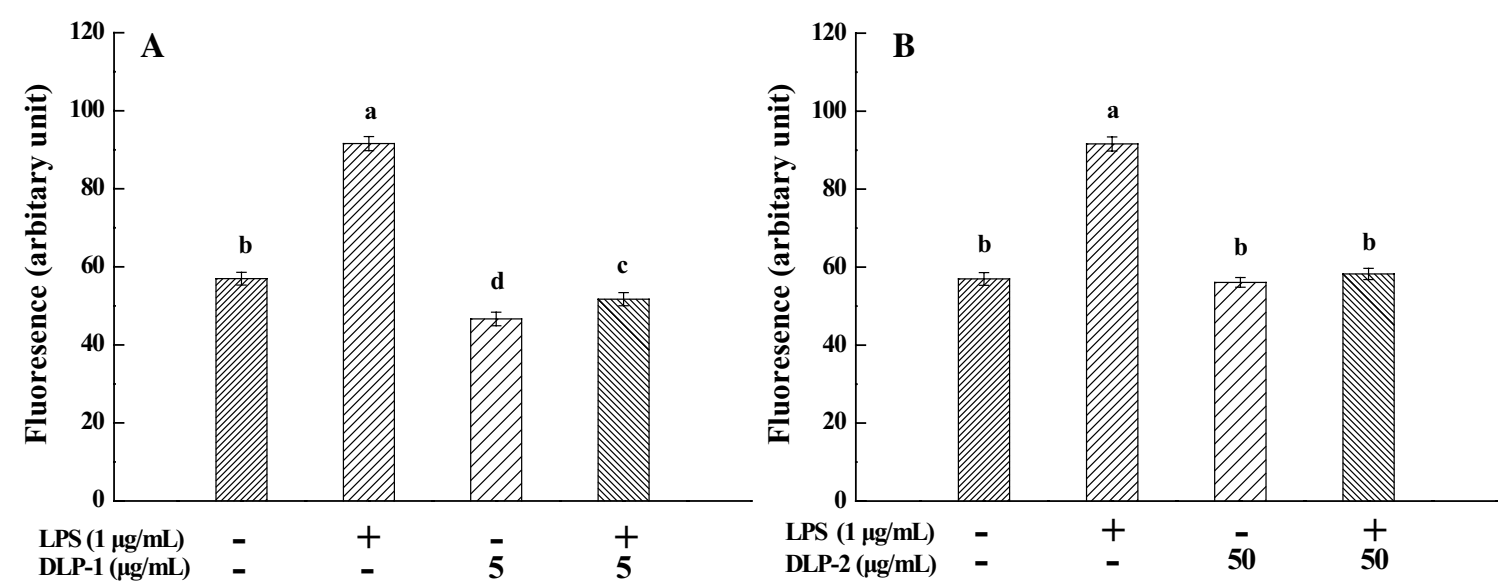

Fig. 3 Effects of DLP-1 and DLP-2 on reactive oxygen species (ROS) generation. A Cells were treated with LPS (1 $\mu \mathrm{g} / \mathrm{mL})$ for $24 \mathrm{~h}$ in the absence or presence of DLP-1 $(5 \mu \mathrm{g} / \mathrm{mL})$. B Cells were treated with LPS $(1 \mu \mathrm{g} / \mathrm{mL})$ for $24 \mathrm{~h}$ in the absence or presence of DLP-2 $(50 \mu \mathrm{g} / \mathrm{mL})$, followed by addition of $10 \mu \mathrm{M}$ DCFH-DA to incubate for $30 \mathrm{~min}$. Values were mean $\pm \mathrm{SD}(\mathrm{n}=3)$, bars with the same letter were not significantly different at $P<0.05$, in accordance with Duncan's multiple range test

polysaccharides in Dendrobium officinale stems [3]. In this study, two polysaccharides were isolated from Dendrobium officinale leaves. DLP-1 consisted of D-(+)-galactose, DL-arabinose, and $\mathrm{L}-(+)$-rhamnose with a mole ratio: 3.21:1.11:0.23. DLP-2 consisted of D-glucose and D-(+)-galactose with a mole ratio: 3.23:1.02. Obviously, there were significant differences in monosaccharide composition of the polysaccharides between Dendrobium officinale leaves and stems.

In addition, inflammation is the body's self-protective behavior. An appropriate inflammatory response can identify pathogens and be beneficial to the body, but

(See figure on next page.)

Fig. 4 Effects of DLP-1 and DLP-2 on mRNA and protein expression of TLR-4, MyD88 and TRAF-6. Cells were treated with LPS (1 $\mu \mathrm{g} / \mathrm{mL})$ for $24 \mathrm{~h}$ in the presence or absence of $\mathbf{A}$ DLP-1 $(5 \mu \mathrm{g} / \mathrm{mL})$ and $\mathbf{B} D L P-2(50 \mu \mathrm{g} / \mathrm{mL})$, respectively. The mRNA expression levels were determined by qRT-PCR. The protein expression was detected by western blotting assay. $\beta$-Actin was used as loading control. Values were mean $\pm S D(n=3)$, bars with the same letter were not significantly different at $P<0.05$, in accordance with Duncan's multiple range test 


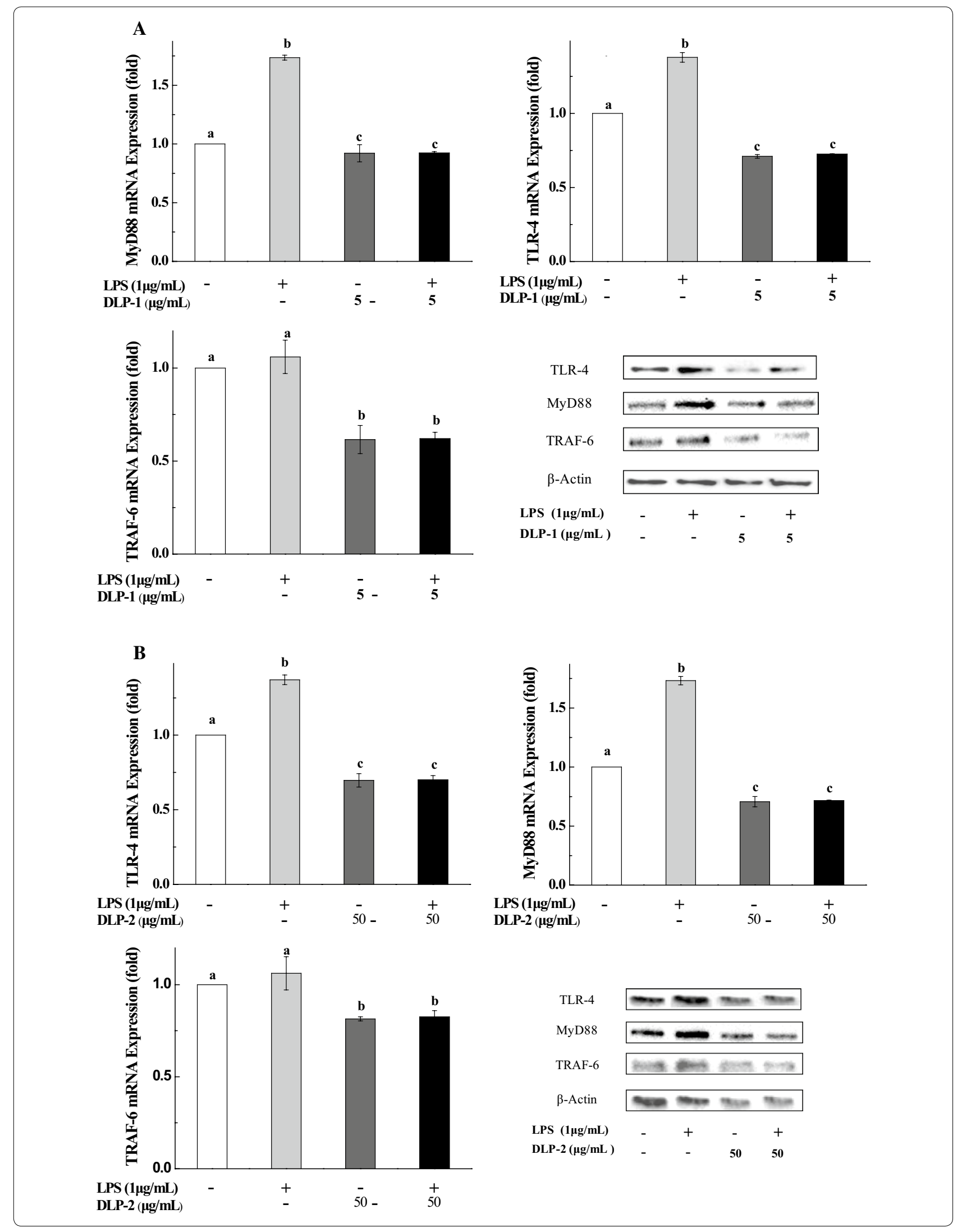


excessive inflammation will do harm to cells and tissues, thereby leading to many diseases, including arthritis, heart disease, cancer, neurological disorders, obesity and diabetes [20]. The polysaccharides extracted from plants represent a structurally diverse class of macromolecules and have been proven to possess a variety of biological activities, especially anti-inflammatory activity [21]. In our research, the polysaccharides from Dendrobium officinale leaves were able to completely counteract the effects of LPS-induced cytotoxicity on THP-1 cells, as well as blocking ROS formation, suggesting they can be used as anti-inflammatory agents.

In the study of the anti-inflammatory mechanism, DLP-1 and DLP-2 exhibited anti-inflammatory activities through inhibition of the activation of TLR-4/MyD88/ TRAF-6 pathway at mRNA and protein levels. Toll-like receptor-4 (TLR-4) is a type of pattern recognition receptors (PRRs) that recognize conserved pathogen-associated molecular patterns, mainly expressed on cells of the innate immune system. The adapter protein myeloid differentiation factor 88 (MyD88), as an immediate adaptor molecule, plays a critical role in activating IRAK-1 and IRAK-4 of signaling cascades [22, 23]. Upon activation of TLR-4 signaling pathways, MyD88 is recruited by combining with TLR-4, IRAK1, IRAK-4 and forming a complex. Following recruitment to MyD88, the rapid autophosphorylation happens to IRAK-1 and make it dissociate from the signaling complex $[24,25]$. Dissociated IRAK1 subsequently interacts with TRAF- 6 and triggers the activation of a kinase cascade involving $І \kappa \textrm{B}$ kinase (IKK), which culminates in the phosphorylation and degradation of $\mathrm{I} \mathrm{KB}$ (NF- $\mathrm{kB}$ inhibitor), subsequently empowers NF- $\mathrm{KB}$ to enter the nucleus, and triggers pro-inflammatory gene expression [26, 27]. The TLR-4 signaling pathway was considered to play a key role in inflammatory processes $[28,29]$. Therefore, therapeutics targeting TLR-4 signaling pathways were expected to safely alleviate chronic inflammatory conditions without compromising the innate immune response [30,31].

In this study, DLP-1 and DLP-2 significantly suppressed mRNA expression of TLR-4, MyD88 and TRAF-6 in LPS-stimulated THP-1 cells. The western blotting results showed that DLP-1 and DLP-2 downregulated the protein expression of TLR-4, MyD88 and TRAF-6, suggesting that influences of polysaccharides on protein expression of TLR-4, MyD88 and TRAF- 6 were corresponding to the effects on their mRNA expression. In summary, these results demonstrated that DLP-1 and DLP-2 exhibited anti-inflammatory activity by inhibiting the activation of TLR-4/MyD88/TRAF-6 pathway at mRNA and protein levels. This is similar to the polysaccharides in the stems [32]. The biological activities of polysaccharides were intimately relevant to the molecular weight, monosaccharide, glycosidic-linkage composition, functional groups, branching characteristics and conformation $[33,34]$. Therefore, the differences in concentrations of anti-inflammatory actions between DLP-1 and DLP-2 might be related to the above factors, which need to be further studied.

\section{Materials and methods \\ Materials and reagents}

Dendrobium officinale leaves were collected from Zhejiang province of China. RPMI 1640 medium and fetal bovine serum (FBS) were purchased from Invitrogen (Carlsbad, CA, USA). 2',7'-dichlorofluorescin diacetate (DCFH-DA), lipopolysaccharide (LPS), dimethyl sulfoxide (DMSO), buffered solution (PBS) and 3-(4,5-dimethylthiazol-2-yl)-2,5-diphenyl tetrazolium bromide (MTT) were purchased from Sigma-Aldrich (St. Louis, MO, USA). $\mathrm{NaCl}, \mathrm{C}_{2} \mathrm{H}_{5} \mathrm{OH}, \mathrm{NaOH}, \mathrm{H}_{2} \mathrm{SO}_{4}, \mathrm{HCl},\left(\mathrm{CH}_{3} \mathrm{CO}\right)_{2} \mathrm{O}$, TCA, TFA, phenol, hydroxylamine hydrochloride, petroleum ether, pyridine, and chloroform were obtained from Sinopharm Chemical Reagent Co., Ltd (Shanghai, China). TGX Stain-Frree FastCast Acrylamide Kit (TGX FastCast), enhanced chemiluminescence reagents (ECL) and transfer buffer provided by Bio-Rad Laboratories (Shanghai, China). $\beta$-Actin, anti-MyD88, anti-TRAF-6 and antirabbit IgG antibodies were bought from Cell Signaling Technology (Danvers, MA, USA). Anti-TLR-4 was provided by AbCam (Cambridge, MA, Britain).

\section{Isolation of polysaccharides}

Dendrobium officinale leaves were dried and crushed into powder, followed by addition of petroleum ether $(1: 5, \mathrm{w} / \mathrm{v}$, solid/liquid ratio) to remove fat-soluble ingredients. The skimmed sample was extracted with distilled water $\left(1: 30 \mathrm{solid} /\right.$ liquid ratio) at $70{ }^{\circ} \mathrm{C}$ for $120 \mathrm{~min}$. Subsequently, aqueous extracts were collected, filtered, evaporated and precipitated by addition of $85 \%$ ethanol $\left(4{ }^{\circ} \mathrm{C}\right.$, $24 \mathrm{~h})$. The precipitation was gathered through centrifugation $\left(4{ }^{\circ} \mathrm{C}, 4000 \mathrm{~g}, 20 \mathrm{~min}\right)$, and then freeze-dried. After deproteinized using Sevag's method, the sample was dialyzed (3500 Da MWCO) and freeze-dried to obtain the crude polysaccharides, named as DLP.

$2 \mathrm{~mL}$ of DLP solution $(100 \mathrm{mg} / \mathrm{mL})$ was added to a DEAE-52 cellulose chromatography column, and then eluted at a $1.0 \mathrm{~mL} / \mathrm{min}$ flow rate with distilled water and $\mathrm{NaCl}$ solution $(0.05,0.1,0.3,0.4 \mathrm{~mol} / \mathrm{L}$ sequentially). $4 \mathrm{~mL}$ eluent was collected in each tube. Two completely separated fractions, A and B, were gathered by measuring eluent absorbance at $490 \mathrm{~nm}$ according to the phenol-sulfuric acid method. Fraction A and B were dialyzed (3500 Da MWCO) and lyophilized. Then $2 \mathrm{~mL}$ of solution A or B $(100 \mathrm{mg} / \mathrm{mL})$ was further purified using Sephadex G-100 column. The column was 
Table 3 PCR primer sequences used in this study

\begin{tabular}{|c|c|c|}
\hline Gene & Sense primer & Antisense primer \\
\hline GAPDH & 5'-AAA TCC CAT CAC CAT CTT CC-3' & 5'-GCA GAG ATG ATG ACC CTTT-3' \\
\hline TLR-4 & 5'-ATG CCT GTG CTG AGT TT-3' & 5'-CTC TAC CAT ACTTTA TGC AGC C-3' \\
\hline MyD88 & 5'-CTA GGT GGG AAA GTC CCA TCA-3' & 5'-TCT TCC TCT CTC TGT GCT TCA TTA-3' \\
\hline TRAF-6 & 5'-TCC TTG CCC TGT TCT CAA T-3' & 5'-GCA TGG AAC GTG TGG AT-3' \\
\hline
\end{tabular}

eluted at a $0.5 \mathrm{~mL} / \mathrm{min}$ flow rate with distilled water and $0.3 \mathrm{~mol} / \mathrm{L} \mathrm{NaCl}$ solution. After dialyzed (3500 Da MWCO) and lyophilized, two purified polysaccharides named DLP-1 and DLP-2 were obtained.

\section{Determination of molecular weight}

The average molecular weights of DLP-1 and DLP-2 were measured by a waters 2695 gel permeation chromatography (GPC) system equipped with three columns of HR3, HR4, HR5 $(7.8 \times 300 \mathrm{~mm})$ and a Waters 2414 Refractive Index Detector. Sample size was $50 \mu \mathrm{L}$, and pure water was used as mobile phase at a flow rate of $1 \mathrm{~mL} / \mathrm{min}$. The column temperature was controlled at $40{ }^{\circ} \mathrm{C}$ during $45 \mathrm{~min}$ of the operation time. The standard curve was established with PEG standard.

\section{Analysis of monosaccharide composition}

GS-MS was used for detecting the monosaccharide composition of DLP-1 and DLP-2. $5 \mathrm{mg}$ of DLP-1 and DLP-2 were accurately weighed,and then mixed with $2 \mathrm{~mL}$ TFA $(2 \mathrm{~mol} / \mathrm{L})$ in sealed ampoule and incubated for $8 \mathrm{~h}$ at $120{ }^{\circ} \mathrm{C}$. After the vacuum-rotary evaporation procedure was adopted to remove TFA, the hydrolyzate was dissolved in $0.5 \mathrm{~mL}$ pyridine and reacted with $10.0 \mathrm{mg}$ hydroxylamine hydrochloride at $90{ }^{\circ} \mathrm{C}$ for $0.5 \mathrm{~h}$. The mixture was cooled to $25{ }^{\circ} \mathrm{C}$ and concentrated by rotary evaporator, followed by addition of $1 \mathrm{~mL}$ chloroform and centrifugation. $1 \mu \mathrm{L}$ of supernatant was injected onto GC-MS system (Agilent Technologies, 77890A-5975C, USA) equipped with a DB-5MS column $(30 \mathrm{~m} \times 0.25 \mathrm{~mm} \times 0.25 \mu \mathrm{m}$, Agilent). The operation parameters were as follows: the $\mathrm{N}_{2}$ flow rate $1 \mathrm{~mL} / \mathrm{min}$, injection temperature $270{ }^{\circ} \mathrm{C}$, ion source temperature $230{ }^{\circ} \mathrm{C}$. The column temperature was programmed from $100{ }^{\circ} \mathrm{C}$ (hold $2 \mathrm{~min}$ ) to $190{ }^{\circ} \mathrm{C}$ at a heating rate of $20{ }^{\circ} \mathrm{C} / \mathrm{min}$, and then increased at $3{ }^{\circ} \mathrm{C} / \mathrm{min}$ to $260{ }^{\circ} \mathrm{C}$, finally at $10{ }^{\circ} \mathrm{C} / \mathrm{min}$ to $300{ }^{\circ} \mathrm{C}$ (hold $4 \mathrm{~min}$ ). Eight monosaccharide standards (L- $(+)$-rhamnose, DL-arabinose, L-(-)-fucose, D-xylose, D-allose, $\mathrm{D}-(+)$-mannose, D-glucose and $\mathrm{D}-(+)$-galactose) were handled in the same way.

\section{Cell culture}

THP-1 cells were purchased from Chinese Academy of Science cell bank (Shanghai, China). RPMI-1640 medium containing $10 \%$ FBS was used for THP-1 cells culture and the Petri dish were incubated at $37{ }^{\circ} \mathrm{C}$ in a $5 \% \mathrm{CO}_{2}$ atmosphere.

\section{MTT assay}

The effect of DLPs on cell viability was determined by MTT assay. In brief, TPH-1 cells were seeded in a 96-well plate at a density of $1 \times 10^{5}$ cells each well for $12 \mathrm{~h}$, and further treated with DLPs at different concentrations for another $24 \mathrm{~h}$. Then, $180 \mu \mathrm{L}$ serum-free medium and $20 \mu \mathrm{L}$ MTT solution $(5 \mathrm{mg} / \mathrm{mL})$ were added to the corresponding wells. After $4 \mathrm{~h}$ of incubation, $150 \mu \mathrm{L}$ DMSO was added as a solvent to dissolve formazan crystals. Finally, the absorbance value at $550 \mathrm{~nm}$ was quantitated with ELISA plate reader (Model 680; Bio-Rad, Hercules, CA).

\section{Intracellular ROS assay}

The cells were seeded in 24-well plates in RPMI 1640 medium containing 10\% FBS and incubated for 18-24 h. Then, the final concentrations of $0.1 \%$ DMSO and $1 \mu \mathrm{g} /$ $\mathrm{mL}$ LPS with or without testing sample $(5 \mu \mathrm{g} / \mathrm{mL}$ DLP-1 or $50 \mu \mathrm{g} / \mathrm{mL}$ DLP-2) was added to cell wells and incubated for $24 \mathrm{~h}$. Cells were collected by centrifugation at $300 g$ for $5 \mathrm{~min}$, washed with PBS twice, and then treated with $10 \mu \mathrm{M}$ of DCFH-DA in an incubator for $30 \mathrm{~min}$. At last, cells were washed with PBS twice and transferred onto ice for test of flow cytometry.

\section{Quantitative reverse transcriptase polymerase chain reaction (RT-PCR) analysis}

Total RNA was extracted with RNAiso Plus (Takara, Code No. 9108/9109) and the cDNA was synthesized with PrimeScriptTM RT reagent kit with gDNA Eraser (Takara, Code No. RR047A). Then the relative expression content of mRNA was quantified using Applied Biosystems 7500 Real Time PCR System (Applied Biosystems, Foster City, CA, USA). The primers were showed in Table 3 . The PCR conditions were as follows: stage 1, 1 
reps for $30 \mathrm{~s}$ at $95^{\circ} \mathrm{C}$; stage 2,40 reps for $5 \mathrm{~s}$ at $95^{\circ} \mathrm{C}$, for $34 \mathrm{~s}$ at $60^{\circ} \mathrm{C}$; stage 3,1 reps for $15 \mathrm{~s}$ at $95^{\circ} \mathrm{C}$, for $60 \mathrm{~s}$ at $60{ }^{\circ} \mathrm{C}$, for $15 \mathrm{~s}$ at $95^{\circ} \mathrm{C}$.

\section{Western immunoblot analysis}

The treated THP-1 cells were violently shaken for $10 \mathrm{~min}$ on ice in $200 \mu \mathrm{L}$ RIPA Lysis Buffer. BCA Protein Assay Kit was used to quantify the protein contents. The equal amounts of protein samples, mixed with loading buffer and denatured in boiling water, were separated on a $15 \%$ SDS-PAGE and transferred to the PVDF membranes. Immune complexes were formed by incubation of the proteins with anti-TLR-4, anti-MyD88 and anti-TRAF-6 primary antibodies overnight at $4{ }^{\circ} \mathrm{C}$. Afterwards, the membranes were rinsed and probed with secondary antibodies. Immunoreactive protein blots were visualized with ECL immunoblotting detection reagents and the bands were then analyzed by ChemiDoc ${ }^{\circledR}$ MP Image Lab.

\section{Data statistics}

Quantitative data were expressed as mean \pm standard deviation (SD) from three repeated experiments conducted in a parallel manner. Values were calculated by SPSS Statistics 17.0 in accordance with one way analysis of variance (ANOVA) and Duncan's multiple range tests. $P<0.05$ was accepted to be significantly different.

\section{Authors' contributions}

$\mathrm{KL}$ and JW conceived and designed the experiments; $\mathrm{MZ}$ and JH conducted the experiments; $\mathrm{HS}$ analyzed the data. All authors read and approved the final manuscript.

\section{Author details}

1 Department of Biopharmaceutics, College of Food Science and Technology, Shanghai Ocean University, 999 Hucheng Ring Road, Lingang New City, Shanghai 201306, China. ${ }^{2}$ National Experimental Teaching Demonstration Center for Food Science and Engineering, Shanghai Ocean University, Shanghai 201306, China.

\section{Acknowledgements}

All authors very appreciate the supports by National Natural Science Foundation of China (81001024, 81572989).

\section{Competing interests}

The authors declare that they have no competing interests.

\section{Publisher's Note}

Springer Nature remains neutral with regard to jurisdictional claims in published maps and institutional affiliations.

Received: 1 September 2018 Accepted: 24 October 2018

Published online: 31 October 2018

\section{References}

1. Zhang LC, Chen J, Lv YL, Gao C, Guo SX (2012) Mycena sp., a mycorrhizal fungus of the orchid Dendrobium officinale. Mycol Prog 11(2):395-401

2. Xing S, Zhang X, Ke H, Lin J, Huang Y, Wei G (2018) Physicochemical properties of polysaccharides from Dendrobium officinale by fractional precipitation and their preliminary antioxidant and anti-HepG2 cells activities in vitro. Chem Cent J 12(1):100. https://doi.org/10.1186/s1306 5-018-0468-4

3. Luo QL, Tang ZH, Zhang XF, Zhong YH, Yao SZ, Wang LS, Luo X (2016) Chemical properties and antioxidant activity of a water-soluble polysaccharide from Dendrobium officinale. Int J Biol Macromol 89:219-227

4. Wei W, Feng L, Bao WR, Ma DL, Leung CH, Nie SP, Han QB (2016) Structure characterization and immunomodulating effects of polysaccharides isolated from Dendrobium officinale. J Agric Food Chem 64(4):881-889

5. Ng TB, Liu J, Wong JH, Ye X, Sze S, Tong Y, Zhang KY (2012) Review of research on Dendrobium, a prized folk medicine. Appl Microbiol Biot 93(5):1795-1803

6. Liu XF, Zhu J, Ge SY, Xia LJ, Yang HY, Qian YT, Ren FZ (2011) Orally administered Dendrobium officinale and its polysaccharides enhance immune functions in BALB/c mice. Nat Prod Commun 6(6):867-870

7. Shi HF (2005) A study on the principles of the prescription of antipyretic and heat-relieving medicated diets and food therapy and their cooking characteristics. Cuisine J Yangzhou Univ 2:35-48

8. Zhang Y (2016) physicochemical properties, antioxidant and immunomodulatory activities of polysaccharides from the stem, leaf and flower of Dendrobium candidum (Master's Thesis). Zhejiang University, Hanzhou, Zhejiang

9. Zhou GF, Pang MX, Chen SH, Lv GY, Yan MQ (2014) Comparison on polysaccharide content and PMP-HPLC fingerprints of polysaccharide in stems and leaves of Dendrobium officinale. China J Chin Mater Med 39(5):795-802

10. Song YH, Cai DL, Fu JY, Xia Y, Xu CJ, Lu W (2016) A study on the effects of Dendrobium candidum leaves on the two generation reproduction female rats' immune function. Zhejiang Prev Med 28(2):109-112

11. Chen XM, Wang FF, Wang YQ, Li XL, Wang AR, Wang CL, Guo SX (2012) Discrimination of the rare medicinal plant Dendrobium officinale based on naringenin, bibenzyl, and polysaccharides. Sci China Life Sci 55(12):1092-1099

12. Liu J, Willför S, Xun CL (2015) A review of bioactive plant polysaccharides: biological activities, functionalization, and biomedical applications. Bioact Carbohydr Diet Fibre 5(1):31-61

13. Basu S, Ghosh M, Bhunia RK, Ganguly J, Banik BK (2017) Polysaccharides from Dolichos biflorus Linn and Trachyspermum ammi Linn seeds: isolation, characterization and remarkable antimicrobial activity. Chem Cent J 11(1):118. https://doi.org/10.1186/s13065-017-0349-2

14. Xia LJ, Liu XF, Guo HY, Zhang H, Zhu J, Ren FZ (2012) Partial characterization and immunomodulatory activity of polysaccharides from the stem of Dendrobium officinale (Tiepishihu) in vitro. J Funct Foods 4(1):294-301

15. Chanput W, Mes JJ, Wichers HJ (2014) THP-1 cell line: an in vitro cell model for immune modulation approach. Int Immunopharmacol 23(1):37-45

16. Chanput W, Mes J, Vreeburg RA, Savelkoul HF, Wichers HJ (2010) Transcription profiles of LPS-stimulated THP-1 monocytes and macrophages: a tool to study inflammation modulating effects of food-derived compounds. Food Funct 1(3):254-261

17. He TB, Huang YP, Yang L, Liu TT, Gong WY, Wang XJ, Hu JM (2016) Structural characterization and immunomodulating activity of polysaccharide from Dendrobium officinale. Int J Biol Macromol 83:34-41

18. Cai HL, Huang XJ, Nie SP, Xie MY, Phillips GO, Cui SW (2015) Study on Dendrobium officinale O-acetyl-glucomannan (Dendronans): part IIIimmunomodulatory activity in vitro. Bioactive Carbohydr Dietary Fibre 5(2):99-105

19. Huang XJ, Nie SP, Cai HL, Zhang GY, Cui SW, Xie MY, Phillips GO (2015) Study on Dendrobium officinale O-acetyl-glucomannan (Dendronan ${ }^{\circledR}$ ): part VI. Protective effects against oxidative stress in immunosuppressed mice. Food Res Int 72:168-173

20. Chao WW, Kuo YH, Li WC, Lin BF (2009) The production of nitric oxide and prostaglandin E2 in peritoneal macrophages is inhibited by Andrographis paniculata, Angelica sinensis and Morus alba ethyl acetate fractions. J Ethnopharmacol 122(1):68-75

21. Lee S, Ji YJ, Ji SS, Kwang SS, Chang W, Young K, Hee D, Kyung T (2015) Immunostimulatory polysaccharide isolated from the leaves of Diospyros kaki thumb modulate macrophage via TLR2. Int J Biol Macromol 79:971-982

22. Takeda K, Akira S (2005) Toll-like receptors in innate immunity. Int Immunol 17(1):1-14 
23. Rhee SH, Hwang D (2000) Murine toll-like receptor 4 confers lipopolysaccharide responsiveness as determined by activation of NFKB and expression of the inducible cyclooxygenase. J Biol Chem 275(44):34035-34040

24. Bryant CE, Symmons M, Gay NJ (2015) Toll-like receptor signalling through macromolecular protein complexes. Mol Immunol 63(2):162-165

25. Lin SC, Lo YC, Wu H (2010) Helical assembly in the MyD88-IRAK4-IRAK2 complex in TLR/IL-1R signalling. Nature 465(7300):885-890

26. Bohannon JK, Hernandez A, Enkhbaatar P, Adams WL, Sherwood ER (2013) The immunobiology of Toll-like receptor 4 agonists: from endotoxin tolerance to immunoadjuvants. Shock 40(6):451-462

27. Frazão JB, Errante PR, Condino-Neto A (2013) Toll-like receptors' pathway disturbances are associated with increased susceptibility to infections in humans. Arch Immunol Ther Ex 61(6):427-443

28. Koh W, Shin JS, Lee J, Lee IH, Lee SK, Ha IH (2017) Anti-inflammatory effect of Cortex Eucommiae via modulation of the toll-like receptor 4 pathway in lipopolysaccharide-stimulated RAW 264.7 macrophages. J Ethnopharmacol 209:255-263
29. Jia SJ, Niu PP, Cong JZ, Zhang BK, Zhao M (2014) TLR4 signaling: a potential therapeutic target in ischemic coronary artery disease. Int Immunopharmacol 23(1):54-59

30. Roy A, Srivastava M, Saqib U, Liu D, Faisal SM, Sugathan S, Baig MS (2016) Potential therapeutic targets for inflammation in toll-like receptor 4 (TLR4)-mediated signaling pathways. Int Immunopharmacol 40:79-89

31. O'Neill LA, Bryant CE, Doyle SL (2009) Therapeutic targeting of toll-like receptors for infectious and inflammatory diseases and cancer. Pharmacol Rev 61(2):177-197

32. Li JW, Li GW, Qin Y, Li CX (2016) Effects of polysaccharides of Dendrobium candidum on overexpression of inflammatory factors in diabetic rats with retinopathy. J Tradit Chin Ophthalmol 26(1):7-11

33. Xu SY, Huang XS, Cheong KL (2017) Recent advances in marine algae polysaccharides: isolation, structure, and activities. Mar Drugs 15(12):388

34. Ferreira SS, Passos CP, Madureira P, Vilanova M, Coimbra M (2015) Structure-function relationships of immunostimulatory polysaccharides: a review. Carbohyd Polym 132:378-396
Ready to submit your research? Choose BMC and benefit from:

- fast, convenient online submission

- thorough peer review by experienced researchers in your field

- rapid publication on acceptance

- support for research data, including large and complex data types

- gold Open Access which fosters wider collaboration and increased citations

- maximum visibility for your research: over $100 \mathrm{M}$ website views per year

At BMC, research is always in progress.

Learn more biomedcentral.com/submissions 